\title{
Effects of gill abrasion and experimental infection with Tenacibaculum maritimum on the respiratory physiology of Atlantic salmon Salmo salar affected by amoebic gill disease
}

\author{
Mark D. Powell ${ }^{1, *}$, James O. Harris ${ }^{1}$, Jeremy Carson ${ }^{2}$, Jonathan V. Hill ${ }^{1}$ \\ ${ }^{1}$ School of Aquaculture, Tasmanian Aquaculture and Fisheries Institute, University of Tasmania, Locked Bag 1370, \\ Launceston, Tasmania 7250, Australia \\ ${ }^{2}$ Fish Health Laboratory, Tasmanian Aquaculture and Fisheries Institute, Department of Primary Industries, Water and \\ Environment, PO Box 46, Kings Meadows, Tasmania 7249, Australia
}

\begin{abstract}
The effects of gill abrasion and experimental infection with Tenacibaculum maritimum were assessed in Atlantic salmon Salmo salar with underlying amoebic gill disease. The respiratory and acid-base parameters arterial oxygen tension $\left(P_{\mathrm{a}} \mathrm{O}_{2}\right)$, arterial whole blood oxygen content $\left(C_{\mathrm{a}} \mathrm{O}_{2}\right)$, arterial $\mathrm{pH}\left(\mathrm{pH}_{\mathrm{a}}\right)$, haematocrit and haemoglobin concentrations were measured at intervals over a $48 \mathrm{~h}$ recovery period following surgical cannulation of the dorsal aorta. Mortality rates over the recovery period were variable, with gill abrasion and inoculation with $T$. maritimum causing the highest initial mortality rate and unabraded, uninoculated controls showing the lowest overall mortality rate. Fish with abraded gills tended to show reduced $P_{\mathrm{a}} \mathrm{O}_{2}$ and lower $C_{\mathrm{a}} \mathrm{O}_{2}$ compared with unabraded fish. Infection with T. maritimum had no effect on $P_{\mathrm{a}} \mathrm{O}_{2}$ or $C_{\mathrm{a}} \mathrm{O}_{2}$. All fish showed an initial alkalosis at $24 \mathrm{~h}$ post-surgery/inoculation which was more pronounced in fish inoculated with T. maritimum. There were no significant effects of gill abrasion or infection upon the ratio of oxygen specifically bound to haemoglobin or mean cellular haemoglobin concentration. Histologically, $48 \mathrm{~h}$ following surgery, abraded gills showed multifocal hyperplastic lesions with pronounced branchial congestion and telangiectasis, and those inoculated with T. maritimum exhibited focal areas of branchial necrosis and erosion associated with filamentous bacterial mats. All fish examined showed signs of amoebic gill disease with multifocal hyperplastic and spongious lesions with parasome-containing amoeba associated with the gill epithelium. The results suggest that respiratory compromise occurred as a consequence of gill abrasion rather than infection with T. maritimum.
\end{abstract}

KEY WORDS: Atlantic salmon · Tenacibaculum maritimum · Respiration · Pathophysiology · Gill disease · Gill abrasion

Resale or republication not permitted without written consent of the publisher

\section{INTRODUCTION}

Amoebic gill disease (AGD), putatively caused by the amphizoic amoeba Neoparamoeba pemaquidensis, is a significant disease for marine aquaculture affecting salmonids and non-salmonid species such as turbot, sea bass and sea bream (for review see Nowak et al. 2002). Although known to cause acute multifocal branchial hyperplastic lesions involving the fusion of gill lamellae and a mucous cell hyperplasia (Adams \& Nowak 2001, Roberts \& Powell 2003), clinical AGD results in few respiratory disturbances (Powell et al. 2000, Powell \& Nowak 2003). The assessment of AGD in salmon is by examination of raised white mucoid patches on the gills, which requires the separation of the gill arches for visual examination. This exposes the fish to branchial trauma and abrasion. 
Tenacibaculum maritimum (formerly Flexibacter maritimus) affects a wide variety of species including red seabream Pagrus major, black seabream Acanthopagrus schegeli, rock bream Oplegnathus fasciatus, Japanese flounder Paralichthys olivaceus (Baxa et al. 1986, Wakabayashi et al. 1986), Dover sole Solea solea (Bernardet et al. 1990), turbot Scophthalmus maximus (Alsina \& Blanch 1993), Atlantic salmon Salmo salar, rainbow trout Onchorynchus mykiss, striped trumpeter Latris lineata and greenback flounder Rhombosolea taprina (Handlinger et al. 1997). Although primarily a skin infection causing ulcerative dermatitis (Handlinger et al. 1997), gill infections where a necrotizing branchitis occurs are not uncommon (Handlinger et al. 1997). Gill abrasion has been reported to enhance the susceptibility of catfish Ictalurus punctatus to infection with Flavobacterium columnare (Bader et al. 2003), and skin abrasion has been used to enhance infections of salmonids to T. maritimum (J. Carson pers. comm.). Therefore, the aim of this study was to investigate the respiratory effects of gill abrasion, acute branchitis caused by an experimentally induced $T$. maritimum infection, and their interaction in Atlantic salmon exhibiting sub-clinical amoebic gill disease.

\section{MATERIALS AND METHODS}

Preparation of bacterial cultures. A culture of Tenacibaculum maritimum was isolated in 2000 by the Department of Primary Industry Water and Environment from the skin of salt water farmed rainbow trout exhibiting cutaneous erosion in Tasmania, Australia. The culture was designated 00/3280. The bacteria were isolated on the medium of Anacker \& Ordal (1959) formulated with seawater. Isolates were identified using a $16 \mathrm{~S}$ rRNA PCR primer set specific for T. maritimum (Carson 1998). Cultures were stored frozen at $-80^{\circ} \mathrm{C}$ on MicroBank (Pro-Lab Diagnostics) beads until required.

Cultures for infection trials were prepared by inoculating $200 \mathrm{ml}$ of Shieh's medium (Song et al. 1988) formulated with seawater mineral salts buffer (MSB) in a 11 conical flask and incubated with gentle agitation $\left(30\right.$ cycles $\mathrm{min}^{-1}$ ) at 20 to $22^{\circ} \mathrm{C}$ for $48 \mathrm{~h}$. The cell suspension was harvested by centrifugation at $2500 \times g \mathrm{RCF}$ for $20 \mathrm{~min}$ and the pellet washed twice with sterile seawater. Harvested cells were resuspended in $15 \mathrm{ml}$ sterile seawater. Cell numbers were determined using serial dilution.

Fish, surgical procedures and inoculation. Atlantic salmon Salmo salar (mean mass \pm SE: $579.3 \pm 27.6$ g; fork length $\pm \mathrm{SE}: 37.8 \pm 0.4 \mathrm{~cm}$ ) were originally obtained from
Springfield Fisheries, Scottsdale, Tasmania. Fish were maintained in the laboratory for at least $1 \mathrm{yr}$ in full strength seawater (35 ppt) at 15 to $17^{\circ} \mathrm{C}$ and fed a commercial pelleted diet to satiation daily. During the acclimation/holding period the salmon naturally acquired a low level of amoebic gill disease (not readily determined by gross pathology). Fish were anaesthetised with $0.03 \mathrm{ml} \mathrm{l}^{-1}$ clove oil in aerated seawater then transferred to a surgical table where they were maintained under anaesthesia with $0.015 \mathrm{ml} \mathrm{l}^{-1}$ clove oil in chilled aerated seawater flowing over the gills in a retrograde direction. Fish were cannulated via the dorsal aorta as described for trout by Soivio et al. (1975) with a PE50 (Clay Adams) cannula filled with Cortland's marine fish saline (Wolf 1963, Milligan et al. 1991).

Following surgery, while still under anaesthesia, the gill filaments were separated by gently stroking (abrasion) using a blunt sterile spatula on both sides. Fish were directly inoculated by pipetting $1 \mathrm{ml}$ of seawater Tenacibaculum maritimum suspension $\left(\sim 2 \times 10^{12} \mathrm{CFU}\right.$ $\mathrm{ml}^{-1}$ ) onto each side of the gills ( $2 \mathrm{ml}$ total per fish) (Group 1, n = 10, Table 1) after Powell et al. (2004). Control fish were abraded but not inoculated with bacteria (Group 2, $\mathrm{n}=13$, Table 1). Fish were then placed in a black acrylic box supplied with flowing aerated seawater $\left(16\right.$ to $\left.17^{\circ} \mathrm{C}\right)$. To assess the effect of abrasion and the interaction with $T$. maritimum infection, fish were inoculated with bacteria without prior abrasion (Group 3, n = 7, Table 1) and controls were left unabraded and uninoculated (Group 4, $\mathrm{n}=9$, Table 1).

Blood sampling and analysis. At intervals during the recovery period $(6,12,24,30,36$ and $48 \mathrm{~h})$ a $500 \mu \mathrm{l}$ blood sample was anaerobically withdrawn from the cannula and replaced with an equal volume of heparinised Cortland's marine saline (100 IU lithium heparin, Sigma-Aldrich). Approximately $100 \mu \mathrm{l}$ was injected into oxygen and pH electrodes (Microelectrodes) connected to a Cameron Instrument Company blood gas meter. Twelve microlitres of whole blood was used for determination of whole blood oxygen content using an Oxy-Con (S. Nicol, Department of Physiology, University of Tasmania) calibrated against room air. Duplicate microhaematocrit samples were made in $20 \mu$ l haematocrit tubes and centrifuged at

Table 1. Salmo salar. Number of fish per group, and gill abrasion and bacterial inoculation characteristics of salmon used in the experiment

\begin{tabular}{|lccc|}
\hline Group & No. of fish & Gill abrasion & Inoculation \\
\hline 1 & 10 & Yes & Yes \\
2 & 13 & Yes & No \\
3 & 7 & No & Yes \\
4 & 9 & No & No \\
\hline
\end{tabular}


$10000 \times g$ for 5 min (Statspin RIII, Statspin Technologies) and a $20 \mu \mathrm{l}$ sample of whole blood was used for haemoglobin determination using a commercial haemoglobin assay (Sigma Diagnostics, Procedure 525).

The ratio of oxygen specifically bound to haemoglobin was calculated according to:

$$
\mathrm{O}_{2}: \mathrm{Hb}=\frac{C_{a} \mathrm{O}_{2}-\left(\alpha \times P_{a} \mathrm{O}_{2}\right)}{[\mathrm{Hb}]_{\mathrm{wb}}}
$$

where $C_{\mathrm{a}} \mathrm{O}_{2}$ is the arterial whole blood oxygen content $\left(\mathrm{ml} 100 \mathrm{ml}^{-1}\right), \quad P_{\mathrm{a}} \mathrm{O}_{2}$ is the arterial oxygen tension (mm Hg), $\alpha$ is the oxygen solubility coefficient (from Cameron 1986) and [Hb] $]_{w b}$ is the whole blood haemoglobin concentration (g $100 \mathrm{ml}^{-1}$ ). Mean cellular haemoglobin concentration (MCHC) was calculated according to:

$$
\mathrm{MCHC}=\frac{[\mathrm{Hb}]_{\mathrm{wb}}}{\text { Hct }}
$$

where Hct is the packed cell volume (haematocrit) (\%).

Pathological assessment of gills. Fish surviving $48 \mathrm{~h}$ were euthanised with an overdose of clove oil $\left(>0.03 \mathrm{ml} \mathrm{l}^{-1}\right.$ ). Mucus was swabbed from the gills of all dead and euthanised fish and streaked onto Sheih's marine agar plates (Song et al. 1988). The gills were then removed and fixed in $10 \%$ seawater buffered formalin for histology. Agar plates were incubated at $18^{\circ} \mathrm{C}$ for up to $5 \mathrm{~d}$ and were checked daily for the appearance of colonies typical of Tenacibaculum maritimum.

Formalin fixed gills were embedded in paraffin wax, sectioned at $5 \mu \mathrm{m}$ and stained with haematoxylin and eosin. The proportion of filaments with characteristic multifocal hyperplastic AGD-like lesions (Adams \& Nowak 2001) were determined (Powell et al. 1995, Speare et al. 1997).

Statistical analysis. Different mortality rates between the different treatments lead to an unbalanced design, so treatments were analysed using analysis of variance with time as a factor. Where significant differences occurred, a Student-Newman-Keuls post-hoc analysis was used to determine differences between sample points. p-values of less than 0.05 were considered to be significant.

\section{RESULTS}

Both Tenacibaculum maritimum inoculated-abraded (Group 1) and uninoculated-abraded fish (Group 2) had high initial mortality rates with a plateau in cumulative mortality at $30 \mathrm{~h}$ post-surgery/inoculation and then rising sharply again 30 to $48 \mathrm{~h}$ post-surgery/inoculation (Fig. 1). Fish that were inoculated with T. maritimum but with unabraded gills (Group 3) showed a similar pattern of mortality to those in the abraded groups but the level of mortality was lower up to $30 \mathrm{~h}$ post-surgery/inoculation. However, between 36 and $48 \mathrm{~h}$ the rate of mortality increased rapidly to a final level of mortality similar to that of the abraded groups (Fig. 1). Unabraded and uninoculated control fish (Group 4) showed a low rate of mortality reaching a maximum of $22 \%$ at 48 h (Fig. 1). Bacterial colonies with characteristics typical of T. maritimum (pale yellow, rough, ragged-edged, adherent colonies) were isolated from fish inoculated with bacteria. No T. maritimum-like bacterial colonies were recovered from fish that were not inoculated.

There were no significant effects between treatments or over time for $P_{\mathrm{a}} \mathrm{O}_{2}$ (Fig. 2). However, there were significant decreases in $\mathrm{C}_{\mathrm{a}} \mathrm{O}_{2}$ for fish with abraded gills, both inoculated (Group 4, $F_{4,14}=22.9$, $\mathrm{p}<0.0001$ ) and uninoculated (Group 2, $F_{5,30}=12.5, \mathrm{p}<$ 0.0001 ) with Tenacibaculum maritimum (Fig. 2). There were no significant differences for unabraded inoculated (Group 3, $F_{5,25}=0.335, \mathrm{p}=0.8866$ ) or controls (Group 4, $F_{5,20}=1.01, \mathrm{p}=0.4367$ ) gills (Fig. 2). Abrasion alone (Group 2, noinfection with T. maritimum) and inoculation alone (Group 3) resulted in a significant initial decrease in $\mathrm{pH}_{\mathrm{a}}$ at $12 \mathrm{~h}$ post-surgery, an increase at $24 \mathrm{~h}$, and then a decrease at $36 \mathrm{~h}$ postsurgery $\left(F_{5,37}=7.21, \mathrm{p}<0.0001, F_{5,25}=28.1, \mathrm{p}<0.0001\right.$ respectively. Overall, the Group 3 showed a greater drop in $\mathrm{pH}_{\mathrm{a}}$. Control (Group 4) fish showed a similar significant decrease in $\mathrm{pH}_{\mathrm{a}}$ at $12 \mathrm{~h}$ followed by a significant increase at $24 \mathrm{~h}\left(F_{5,31}=6.07, \mathrm{p}=0.0005\right)$ that was

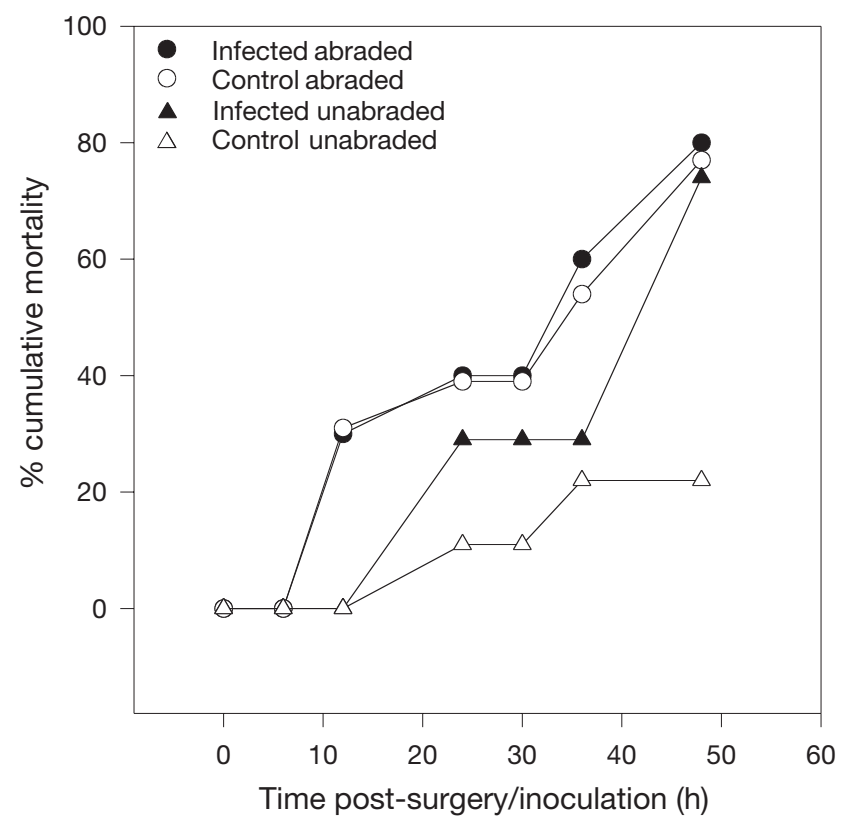

Fig. 1. Salmo salar. Percent cumulative mortality for cannulated Atlantic salmon with abraded (Groups 1 and 2, circles) and unabraded (Groups 3 and 4, triangles) gills infected (solid symbols) and uninfected controls (open symbols) with Tenacibaculum maritimum 

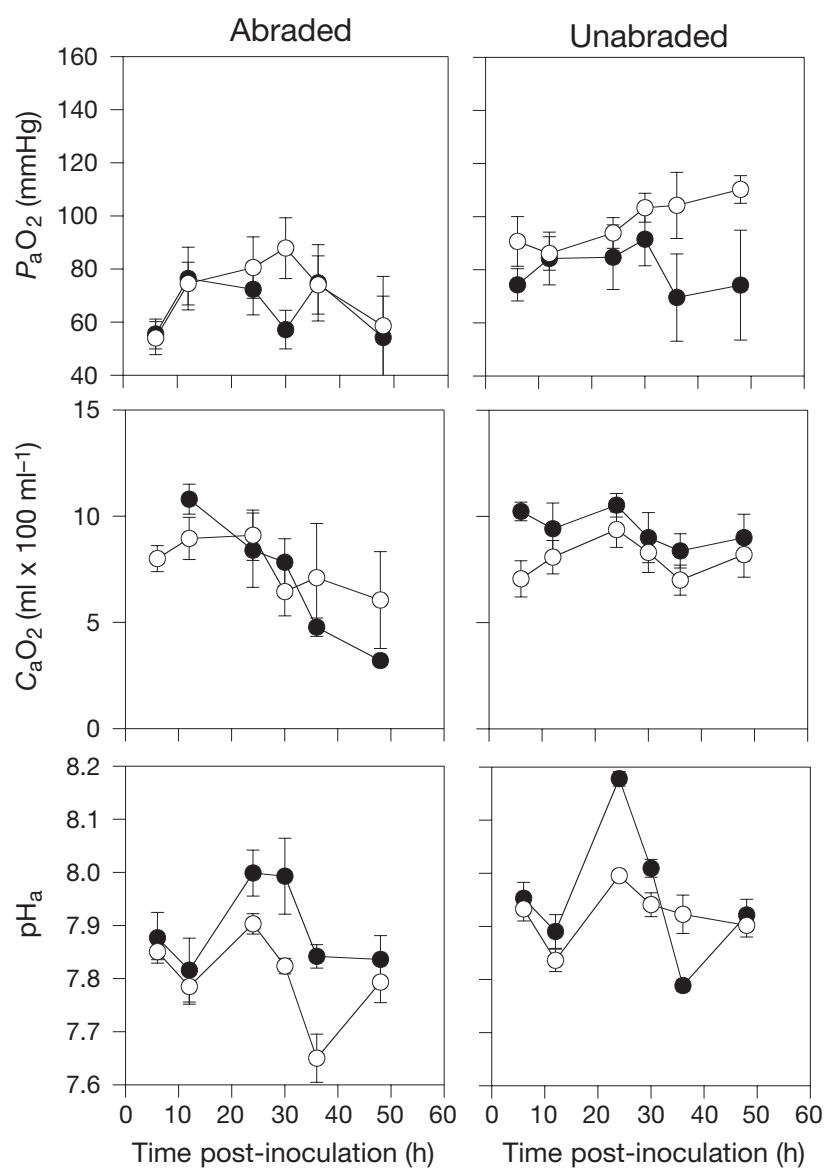

Fig. 2. Salmo salar. Mean $( \pm \mathrm{SE})$ arterial oxygen tension $\left(P_{\mathrm{a}} \mathrm{O}_{2}\right)$, whole blood oxygen content $\left(\mathrm{C}_{\mathrm{a}} \mathrm{O}_{2}\right)$ and $\mathrm{pH}\left(\mathrm{pH}_{\mathrm{a}}\right)$ of AGD-affected Atlantic salmon that had their gills abraded or unabraded and inoculated (Groups 1 and 3, •) or non-inoculated (Groups 2 and 4,0 ) with Tenacibaculum maritimum

maintained until $48 \mathrm{~h}$ post-surgery (Fig. 2). The $\mathrm{pH}_{\mathrm{a}}$ of abraded-inoculated fish (Group 1) was unaffected $\left(F_{5,23}=1.82, \mathrm{p}=0.1476\right)$. There were no significant differences in the amount of oxygen specifically bound to haemoglobin for any of the treatments (Fig. 3). Although variable, the mean cellular haemoglobin concentrations did not differ statistically between groups of change over time (Fig. 3).

All of the fish examined in this study had AGD-like lesions prior to gill abrasion or inoculation with Tenacibaculum maritimum as evidenced by the presence of AGD-like lesions even on the unabraded, uninoculated fish. Histological examination on completion of the experiment showed $17.7 \pm 2.6 \%$ (mean $\pm \mathrm{SE}$ ) of the gill filaments had AGD-type lesions (Fig. 4) with no difference between treatments. The gills from fish that had been abraded (Groups 1 and 2) showed signs of telangiectasis and congestion (Fig. 4). Fish that had been inoculated with T. maritimum (Groups 1 and 3) showed localised regions of close association of fila-
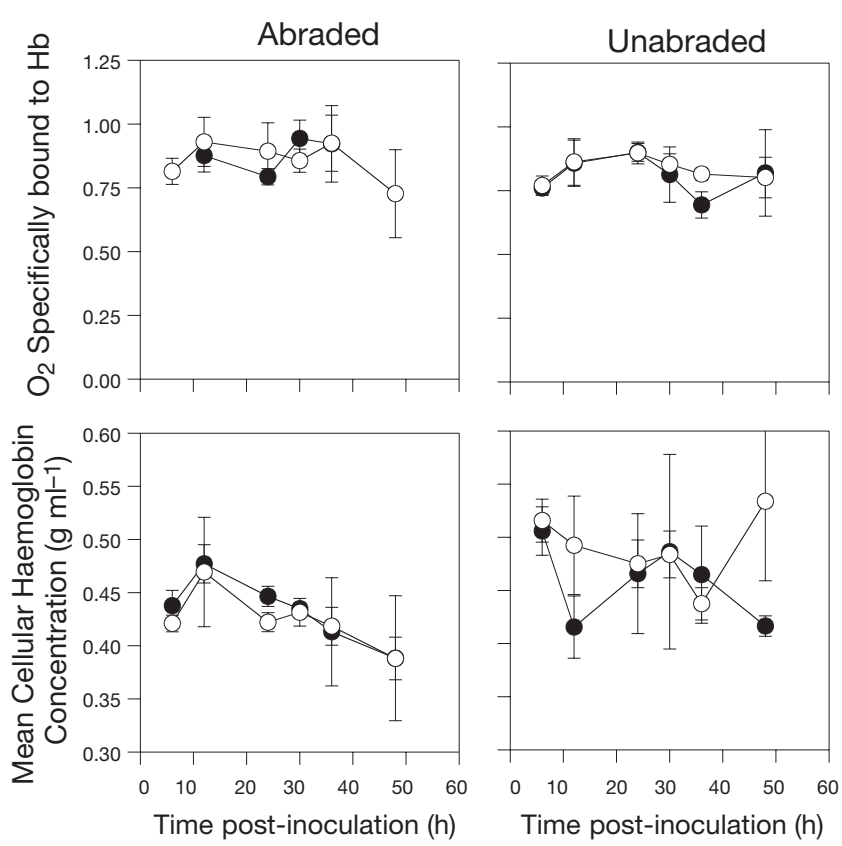

Fig. 3. Salmo salar. Mean $( \pm \mathrm{SE})$ ratio of oxygen specifically bound to haemoglobin and mean cellular haemoglobin concentration of affected by amoebic gil disease (AGD) Atlantic salmon that had their gills abraded or unabraded and inoculated (Groups 1 and 3, $)$ or non-inoculated (Groups 2 and 4, O) with Tenacibaculum maritimum

mentous bacteria with the respiratory epithelium (Fig. 4). Bacteria associated filamental necrosis appeared to progress proximally from the distal part of the filament.

\section{DISCUSSION}

Survival of AGD-compromised salmon following anaesthesia and surgery was comparable to rates seen in other studies (Powell et al. 2000, Powell \& Nowak 2003). Non-AGD-affected salmon usually recover from surgery readily (Powell et al. 2000). In the current study, gill abrasion further decreased the survival of salmon post-surgery irrespective of whether fish were inoculated with Tenacibaculum maritimum.

Gill abrasion leads to extensive telangiectasis (Powell et al. 2004) and this further develops into hyperplastic lesions similar to those seen in fish with AGD (Fig. 4B) and that shown by Adams \& Nowak (2004). It is difficult to visually determine the extent of AGD on fish prior to use, since gill abrasion also leads to AGD-like lesions. However, gill abrasion lesions can be differentiated using histology by the absence of parasome-containing amoebae associated with the lesion (Fig. 4D,E). Histological examination was performed on samples from fish that were moribund or 

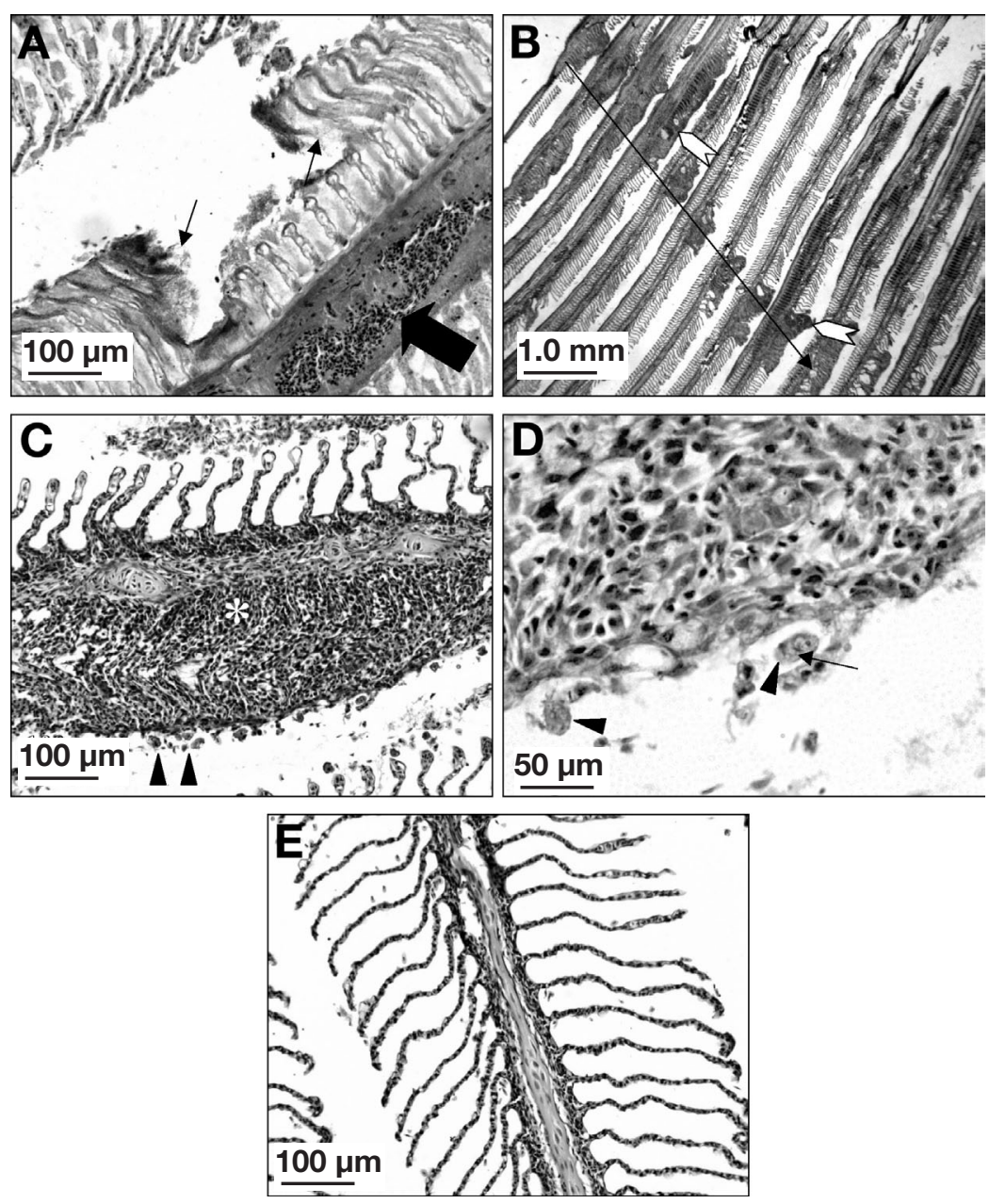

Fig. 4. Salmo salar gills. (A) Focal branchial lamellar necrosis associated with filamentous bacterial mats (small arrows) and congestion in the central venous sinus (large arrow) on the gills of Atlantic salmon inoculated with Tenacibaculum maritimum (H\&E). (B) Hyperplastic lesions associated with gill abrasion (open arrows) and the direction of abrade (long arrow) in the gills of Atlantic salmon (haemotoxylin and eosin, H\&E). (C) A characteristic amoebic gill disease (AGD) lesion with parenchymal hyperplasic tissue (asterisk) and peripherally associated amoebae (arrowheads) (H\&E). (D) Amoebae associated with a hyperplastic AGD-type gill lesion (arrowheads) showing the characteristic parasome of Neoparamoeba sp. (arrow) (H\&E). (E) Non-AGD affected area of the gills of control (uninoculated) Atlantic salmon (H\&E)

$48 \mathrm{~h}$ post-surgery, therefore, the degree of AGD may be greater than that pre-surgery.

Salmon with abraded gills appeared to have a lower arterial $\mathrm{PO}_{2}$ (although not statistically significant) and showed a continuous decline in whole blood oxygen content (Fig. 3) regardless of inoculation with Tenacibaculum maritimum. However, fish with unabraded gills appeared to maintain blood oxygen content and $P_{\mathrm{a}} \mathrm{O}_{2}$ (Fig. 3). Interestingly, none of the treatments reduced the ratio of oxygen specifically bound to haemoglobin, and this ratio remained high. This suggests a rapid recovery from surgery-associated hypo- xaemia and that both abrasion and inoculation had little effect on the saturation of haemoglobin with oxygen, i.e. the oxygen haemoglobin carrying capacity and affinity were unaffected. The apparent differences in blood oxygen (tension and content) between abraded and non-abraded fish is likely explained in terms of diffusional limitation of gas transfer across the compromised gill (Ultsch \& Gros 1979, Powell \& Perry 1999). Indeed, fish with significant structural compromise have severely restricted respiratory performance (Hughes \& Nyholm 1979).

The arterial $\mathrm{pH}$ of all groups returned to normal levels rapidly following surgery with $\mathrm{pH}_{\mathrm{a}}$ values occurring within the expected ranges for salmonids. Interestingly, although the fish had underlying AGD, blood $\mathrm{pH}$ was not compromised with a characteristic acidosis reported previously (Powell et al. 2000, 2001, Powell \& Nowak 2003). The reason for this probably lies in the fact that the respiratory acidosis associated with AGD occurs 3 to $4 \mathrm{~d}$ post-inoculation (M. D. Powell, J. O. Harris \& M. Leef unpubl. data). There was a significant increase in $\mathrm{pH}_{\mathrm{a}}$ in all fish groups between 12 and $24 \mathrm{~h}$ postsurgery/inoculation, with the most pronounced rise in $\mathrm{pH}$ seen in fish inoculated with Tenacibaculum maritimum (Group 3, Fig. 2). Many parasitic infections, as well as chemical irritation, will result in gill mucus production that inhibits carbon dioxide excretion and causes respiratory acidosis (Powell \& Perry 1996, Powell et al. 1998, 2000). Byrne et al. (1991) demonstrated that brook trout Salvelinus fontinalis challenged with Flavobacterium branchiophilum showed no significant change in blood $\mathrm{pH} 1$ and $4 \mathrm{~d}$ postchallenge. In contrast, rainbow trout (Byrne et al. 1995) showed a significant decrease in blood $\mathrm{pH} 24 \mathrm{~h}$ postchallenge. Fish challenged with Neoparamoeba pemaquidensis (putative agent of AGD) show an acute respiratory alkalosis initially ( 1 to $3 \mathrm{~d}$ post-challenge). This is followed by the onset of a respiratory acidosis at 3 to $4 \mathrm{~d}$ post-challenge (M. D. Powell, J. O. Harris \& M. Leef unpubl. data) similar to that seen clinically for AGD (Powell et al. 2000). Therefore, in the present study it is likely that the rise in $\mathrm{pH}_{\mathrm{a}}$ with $T$. maritimum-inoculated fish was indicative of the onset of gill infection as this was not seen in uninoculated fish (Fig. 3). The decline in $\mathrm{pH}_{\mathrm{a}}$ 
of T. maritimum-inoculated fish between 24 and $36 \mathrm{~h}$ post-surgery/inoculation may be equivalent to the acidosis observed in clinically AGD-affected fish. Mortality rates escalated between 36 and $48 \mathrm{~h}$ for inoculated fish, which corresponds with the onset of the acidosis seen in the abraded Fish Groups 1 and 2.

In conclusion, it would appear that gill abrasion causes profound respiratory disturbances that most likely result in reduced post-surgical survival. Infection of the gills with Tenacibaculum maritimum likely caused respiratory disturbances, but only after $30 \mathrm{~h}$. These effects were likely to be also confounded by branchial abrasion. There was no evidence that gill abrasion and T. maritimum inoculation had an additive effect upon mortality. The underlying infection of fish with AGD appeared to have little effect upon the outcome of whether gills were abraded or infected with T. maritimum, suggesting that underlying AGD does not predispose fish to $T$. maritimum infections and vice versa.

Acknowledgements. Thanks to Mr. T. Green for assistance with histology. Funding was provided from an Australian Research Council Large Research Grant to M.D.P.

\section{LITERATURE CITED}

Adams MB, Nowak BF (2001) Distribution and structure of lesions in the gills of Atlantic salmon, Salmo salar L., affected with amoebic gill disease. J Fish Dis 24:535-542

Adams MB, Nowak BF (2004) Experimental amoebic gill disease of Atlantic salmon Salmo salar L.: further evidence for the primary pathogenic role of Neoparamoeba sp. (Page, 1987). J Fish Dis 27:105-113

Alsina M, Blanch AR (1993) First isolation of Flexibacter maritimus from cultivated turbot, Scophthamus maximus. Bull Eur Assn Fish 13:157-160

Anacker RL, Ordal EJ (1959) Studies on the myxobacterium Chondrococcus columnaris. 1. Serological typing. J Bacteriol 78:25-32

Bader JA, Nusbaum KE, Shoemaker CA (2003) Comparative challenge model of Flavobacterium columnare using abraded and unabraded channel catfish, Ictalurus punctatus (Rafinesque). J Fish Dis 26:461-467

Baxa DV, Kawai K, Kusuda R (1986) Characteristics of gliding bacteria isolated from diseased cultured flounder, Paralichthys olivaceus. Fish Pathol 21:251-258

Bernardet JF, Campbell AC, Buswell JA (1990) Flexibacter maritimus is the agent of 'black patch necrosis' in Dover sole in Scotland. Dis Aquat Org 8:233-237

Byrne P, Ferguson HW, Lumsden JS, Ostland VE (1991) Blood chemistry of bacterial gill disease in brook trout, Salvelinus fontinalis. Dis Aquat Org 10:1-6

Byrne PJ, Ostland VE, Lumsden JS, MacPhee DD, Ferguson HW (1995) Blood chemistry and acid-base balance in rainbow trout Oncorhynchus mykiss with experimentally-induced acute bacterial gill disease. Fish Physiol Biochem 14:509-518

Cameron JN (1986) Principles of physiological measurement. Academic Press, London

Carson J (1998) Development of molecular probes for use in bacterial disease diagnosis and health monitoring of farmed and wild finfish in Australia. Fin Rep Project 93/128. Fisheries Research and Development Corporation, Canberra

Handlinger J, Soltani M, Percival S (1997) The pathology of Flexibacter maritimus in aquaculture species in Tasmania, Australia. J Fish Dis 20:159-168

Hughes GM, Nyholm K (1979) Ventilation in rainbow trout (Salmo gairdneri, Richardson) with damaged gills. J Fish Biol 14:285-288

Milligan CL, McDonald DG, Prior T (1991) Branchial acid and ammonia fluxes in response to alkalosis and acidosis in two marine teleosts: coho salmon (Oncorhynchus kisutch) and starry flounder (Platichthys stellatus). Physiol Zool 64:169-192

Nowak BF, Carson J, Powell MD, Dykova I (2002) Amoebic gill disease in the marine environment. Bull Eur Assn Fish P 22:144-148

Powell MD, Nowak BF (2003) Acid-base and respiratory effects of confinement in Atlantic salmon affected with amoebic gill disease. J Fish Biol 62:51-63

Powell MD, Perry SF (1996) Respiratory and acid-base disturbances in rainbow trout (Oncorhynchus mykiss) blood during exposure to chloramine-T, paratoluenesulphonamide and hypochlorite. Can J Fish Aquat Sci 53:701-708

Powell MD, Perry SF (1999) Cardio-respiratory effects of chloramine- $\mathrm{T}$ in rainbow trout. Exp Biol Online 4:5

Powell MD, Speare DJ, Wright GM (1995) Morphological changes in the rainbow trout (Oncorhynchus mykiss) gill epithelia following intermittent exposure to chloramine-T. Can J Zool 73: 154-165

Powell MD, Haman F, Wright GM, Perry SF (1998) Response of rainbow trout (Oncorhynchus mykiss) to a graded hypoxia following repeated intermittent exposure to chloramine-T. Aquaculture 165:27-39

Powell MD, Fisk D, Nowak BF (2000) Effects of graded hypoxia on Atlantic salmon (Salmo salar L.) infected with amoebic gill disease (AGD). J Fish Biol 57:1047-1057

Powell MD, Parsons HJ, Nowak BF (2001) Physiological effects of freshwater bathing of Atlantic salmon (Salmo salar) as a treatment for amoebic gill disease. Aquaculture 199:259-266

Powell M, Carson J van, Gelderen R (2004) Experimental induction of gill disease in Atlantic salmon smolts, Salmo salar, with Tenacibaculum maritimum. Dis Aquat Org 61:179-185

Roberts SD, Powell MD (2003) Comparative ionic flux and gill mucous cell histochemistry: effects of salinity and disease status in Atlantic salmon (Salmo salar L.). Comp Biochem Physiol Part A 134:525-537

Soivio A, Nyholm K, Westman K (1975) A technique for repeated sampling of the blood of individual resting fish. J Exp Biol 62:207-217

Song YL, Fryer JL, Rohovec JS (1988) Comparison of six media for the cultivation of Flexibacter columnaris. Fish Pathol 23:91-94

Speare DJ, Arsenault G, MacNair N, Powell MD (1997) Branchial lesions associated with intermittent formalin bath treatment of Atlantic salmon, Salmo salar L., and rainbow trout, Oncorhynchus mykiss (Walbaum). J Fish Dis 20:27-33

Ultsch GR, Gros G (1979) Mucus as a diffusion barrier to oxygen: possible role in $\mathrm{O}_{2}$ uptake at low $\mathrm{pH}$ in carp (Cyprinus carpio) gills. Comp Biochem Physiol A 62:685-689

Wakabayashi H, Hikida M, Masumura K (1986) Flexibacter maritimus sp. nov., a pathogen or marine fishes. Int J Syst Bacteriol 36:396-398

Wolf K (1963) Physiological salines for freshwater fishes. Prog Fish-Cult 25:135-140

Submitted: July 29, 2004; Accepted: September 28, 2004

Proofs received from author(s): January 14, 2005 